\title{
Spad index for diagnosis of nitrogen status in 'Esmeralda' peach
}

\author{
Jorge Atílio Benati ${ }^{1}$, Gilberto $\mathrm{Nava}^{2}$, Newton Alex Mayer ${ }^{2}$
}

\begin{abstract}
The objective of this research was to evaluate the technical feasibility of SPAD index in the diagnosis of $\mathrm{N}$ status in 'Esmeralda' peach. The field trial, with five $\mathrm{N}$ rates applied to the soil $\left(0,40,80,120\right.$ and $160 \mathrm{~kg} \mathrm{ha}^{-1}$ of $\mathrm{N}$ as urea form) was conducted in a randomized block design with four replications. During the years 2014, 2015, 2016 and 2017, SPAD readings were carried out with a Minolta SPAD-502 chlorophyll meter, in the leaf middle part, in 40 leaves per plot. The leaf $\mathrm{N}$ content determination was performed in CHN-S Elemental Analyzer. SPAD index and leaf $\mathrm{N}$ content increased in a linear way in response to increasing $\mathrm{N}$ rates applied in soil. There was a positive linear correlation between SPAD index and $\mathrm{N}$ concentration in leaves $(0.652 ; 0.756 ; 0.762$ and $0.767, p<0.05)$. SPAD index can be used for nutritional $\mathrm{N}$ diagnosis purpose in peach when readings are taken between the $13^{\text {th }}$ and $15^{\text {th }}$ weeks after full bloom. In the range between 39 and 49 , the SPAD index indicates the leaf $\mathrm{N}$ content is included in "normal" class $\left(33-45 \mathrm{~g} \mathrm{~kg}^{-1}\right)$ of agronomic interpretation for the States of Rio Grande do Sul and Santa Catarina, Brazil.
\end{abstract}

Index terms: Prunus persica, nitrogen fertilization, chlorophyll meter, leaf mineral composition

\section{Índice spad para diagnóstico do estado de nitrogênio em pessegueiro 'Esmeralda'}

Corresponding author: gilberto.nava@embrapa.br

Received: July 23, 2020 Accepted: December 07, 2020

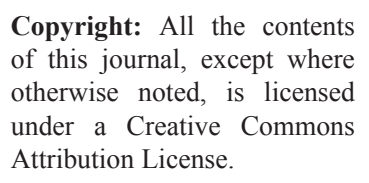
of this journal, except where otherwise noted, is licensed under a Creative Commons Attribution License.

Resumo - O objetivo do presente trabalho foi avaliar a viabilidade técnica do índice SPAD no diagnóstico do estado de $\mathrm{N}$ em pessegueiros $\mathrm{cv}$. Esmeralda. $\mathrm{O}$ experimento, com cinco níveis de $\mathrm{N}$ aplicado no solo $\left(0 ; 40 ; 80 ; 120\right.$ e $160 \mathrm{~kg} \mathrm{ha}^{-1}$ de $\mathrm{N}$ na forma de ureia), foi conduzido a campo, em delineamento experimental de blocos ao acaso, com quatro repetições. Durante os anos de 2014, 2015, 2016 e 2017, realizaram-se leituras com clorofilômetro, modelo Minolta SPAD-502, na parte mediana da folha, em 40 folhas por parcela. A determinação do teor foliar de $\mathrm{N}$ foi realizada em Analisador Elementar CHN-S. O índice SPAD e o teor de N nas folhas aumentaram de forma linear, de acordo com o aumento das doses de $\mathrm{N}$ aplicadas no solo. Houve efeito das doses de $\mathrm{N}$ aplicadas no solo sobre o índice SPAD, e os teores foliares de N apresentaram correlação linear positiva com as leituras $\operatorname{SPAD}(0.652 ; 0.756 ; 0.762$ e $0.767, p<0.05)$. O índice SPAD pode ser utilizado no diagnóstico nutricional de $\mathrm{N}$ em pessegueiro, quando as leituras são realizadas entre a $13^{\mathrm{a}}$ e a $15^{\mathrm{a}}$ semana após a plena floração. Na faixa compreendida entre 39 e 49, o índice SPAD indica que o N foliar está compreendido na classe "normal" (33-45 $\left.\mathrm{g} \mathrm{kg}^{-1}\right)$ de interpretação agronômica, para os Estados do Rio Grande do Sul e de Santa Catarina, Brasil.

Termos para indexação: Prunus persica, adubação nitrogenada, clorofilômetro, composição mineral de folhas.

\footnotetext{
${ }^{1}$ Master in Agronomy, PhD student, Graduate Program in Agronomy, Universidade Federal de Pelotas (UFPel), Capão do Leão-RS, Brasil. E-mail: jorgeatiliobenati@hotmail.com (ORCID 0000-0002-5970-9175)

${ }^{2}$ Researcher, Embrapa Clima Temperado, Pelotas-RS, Brasil. E-mails: gilberto.nava@embrapa.br ${ }^{\text {(ORCID 0000-0002-8059-1052) }}$; alex. mayer@embrapa.br (ORCID 0000-0001-6689-8202)
} 


\section{Introduction}

The evaluation of nutrient contents in peach tree is based on macro ( $\mathrm{N}, \mathrm{P}, \mathrm{K}, \mathrm{Ca}$ and $\mathrm{Mg}$ ) and micronutrient $(\mathrm{B}, \mathrm{Fe}, \mathrm{Cu}, \mathrm{Mn}$ and $\mathrm{Zn}$ ) concentration in leaves collected from the median portion of shoots of the year, between the $13^{\text {th }}$ and $15^{\text {th }}$ weeks after full bloom (CQFS-RS/SC, 2016), a period in which there is greater stability of leaf nutrient concentration and, therefore, considered as a standard for leaf sampling for nutritional diagnosis purposes.

Although levels of leaf nutrients are those that best represent tree nutritional status, the standard period of leaf sampling in peach trees is very close to the fruit harvest season, which makes it difficult to use leaf chemical analysis to adjust fertilization recommendations for the same fruit production cycle (NAVA and CIOTTA, 2013). In addition, it appears that leaf chemical analysis is a technique that is still little used by peach growers in the State of Rio Grande do Sul, mainly due to cost and delay in receiving results, not allowing to be used for recommendation purposes during the current growing cycle.

Indirect methods of determining leaf nutrient content, with quick results, can be useful for technicians and growers to adjust fertilization recommendations. The chlorophyll meter SPAD (Soil Plant Analysis Diagnostic), also called chlorophyll meter, provides immediate readings in a leaf non-destructive way, and appears as an alternative to indicate concentration of some nutrients, mainly $\mathrm{N}$. The readings made by the chlorophyll meter match the leaf chlorophyll content (AMARANTE et al., 2008; CABANGON et. al., 2011), which in turn positively correlates with the leaf $\mathrm{N}$ concentration (NAVA and CIOTTA, 2013; BRUNETTO et al., 2012), since this nutrient is a component of chlorophyll molecule structure.

The potential of using chlorophyll meter for nutritional diagnosis purposes has been evaluated for several fruit trees, such as apple (GARRIZ et al., 2001; NAVA and CIOTTA, 2013; TREDER et al., 2016), citrus (PRADO and VALE, 2008; SOUZA et al, 2011), grapevine (PORRO et al., 2001; BRUNETTO et al., 2012), among others. For these crops, results indicate a satisfactory correlation of SPAD readings with chlorophyll content or total leaf $\mathrm{N}$ content, since approximately $75 \%$ of $\mathrm{N}$ in leaves integrate compounds associated with chloroplasts and chlorophyll content (ROBERTS et al., 2012). The positive relationship between SPAD index and leaf $\mathrm{N}$ content is due the SPAD-502 portable meter quantitatively evaluates the leaf green intensity, measuring light transmissions at $650 \mathrm{~nm}$-(FERREIRA et al., 2006; CEROVIC et al., 2015).

Nitrogen is one of the most important mineral nutrient for tree growth, since it is related to photosynthesis, respiration, root development and activity, cell growth and differentiation, crop yield and fruit quality, in addition to be integral to all amino acids (MARSCHNER, 2012). Therefore, precision for period and $\mathrm{N}$ rate application play an important role in tree nutrition and yield (TREDER et al., 2016).

The objective of this research was to evaluate the technical feasibility of SPAD index to estimate leaf $\mathrm{N}$ levels in 'Esmeralda' peach, in order to anticipate nitrogen fertilization adjustment measures.

\section{Material and methods}

This research was carried out in a commercial peach orchard $\left(31^{\circ} 31^{\prime} 49.3\right.$ " $\mathrm{S}$ and $\left.52^{\circ} 35^{\prime} 39.8^{\prime \prime} \mathrm{W}\right)$ in the municipality of Morro Redondo, Rio Grande do Sul, Brazil. According to Köppen classification, climate is "Cfa" type - humid sub tropical climate, that is humid temperate with hot summers (ALVARES et al., 2013). Precipitation and average monthly air temperatures during trial evaluations were obtained from an automatic weather station ( $\left.31^{\circ} 40^{\prime} 59.6^{\prime \prime} \mathrm{S} ; 52^{\circ} 26^{\prime} 10.3^{\prime \prime} \mathrm{W}\right)$, located at the headquarters of Embrapa Clima Temperado, Pelotas, Rio Grande do Sul, $23 \mathrm{~km}$ in a straight line from the trial site.

The soil was classified as Gray-Brown Argisol (SOIL SURVEY STAFF, 1999) or 'Argissolo Bruno Acinzentado' (Brazilian Soil Classification System, 2013). The initial soil analysis in the $0-20 \mathrm{~cm}$ layer showed the following results: phosphorus of $8.1 \mathrm{mg} \mathrm{dm}^{-3}$; potassium of $69.0 \mathrm{mg} \mathrm{dm}^{-3}$; magnesium of $1.0 \mathrm{cmol}_{\mathrm{c}} \mathrm{dm}^{-3}$; calcium of $2.6 \mathrm{cmol}_{c} \mathrm{dm}^{-3}$; clay of $18.0 \%$; organic matter of $2.3 \%$; effective CEC of 7.5; and SMP buffer of 5.7.

Peach orchard was composed of 5-years-old 'Esmeralda' trees, with $5.0 \mathrm{~m}$ between lines and $1.5 \mathrm{~m}$ between trees $(1,333$ trees ha-1 $)$. The experimental design was randomized blocks with four replications and each plot was composed by four trees with two central useful trees. Annually, each plot received different rates of N: $0,40,80,120$ and $160 \mathrm{~kg} \mathrm{ha}^{-1}$ of $\mathrm{N}$ as urea $(45 \%$ of $\mathrm{N})$. The $\mathrm{N}$ rates were applied to the soil surface throughout scion projection area, without soil incorporation and split in two phases (half at blooming beginning and half at fruit thinning). All plots received equal doses of phosphorus (P) (40 $\mathrm{kg} \mathrm{ha}^{-1}$ of $\mathrm{P}_{2} \mathrm{O}_{5}$ as triple superphosphate) and potassium (K) ( $80 \mathrm{~kg} \mathrm{ha}^{-1}$ of potassium chloride), as recommended by CQFS-RS/SC (2004), followed by soil and leaf chemical analysis. The experimental area received the same cultural management recommended for commercial orchards (RASEIRA; PEREIRA; CARVALHO, 2014), except for $\mathrm{N}$ fertilization.

Measurements of relative chlorophyll content (SPAD index readings) were performed annually in November (between the $13^{\text {th }}$ and $15^{\text {th }}$ weeks after full bloom) of 2014, 2015, 2016 and 2017, with a chlorophyll meter, Minolta SPAD-502 Plus model 2900PDL, with an accuracy of \pm 1 SPAD unit, a measuring area of $2 \mathrm{~mm} \mathrm{x}$ 
$3 \mathrm{~mm}$ and scale ranging from 0 to 50 , which indicates the relative amount of chlorophyll present in the leaf based on the principle of difference in optical density between two wavelengths (MINOLTA, 1989). The SPAD readings were taken on the adaxial limbo side of median part in 40 leaves sampled in two useful trees per plot, at median part of no-shading shoots of the year. In results, the average values of SPAD readings were considered to estimate $\mathrm{N}$ leaf concentration.

Samples (approximately 40 leaves per plot) were collected for chemical analysis from the middle part of no-shaded shoots of the year, on different sides of trees, at same day of the SPAD readings. To determine leaf $\mathrm{N}$ content, leaves were dried in an oven at $65{ }^{\circ} \mathrm{C}$, until constant weight, and grounded. Leaf $\mathrm{N}$ content was determined by combustion method in $\mathrm{LECO}^{\circledR}$ TruSpec CHN-S Elementary Analyzer, where $\mathrm{N}$ is quantified with thermal conductivity cell and results are expressed in $\mathrm{g}$ $\mathrm{kg}^{-1}$.
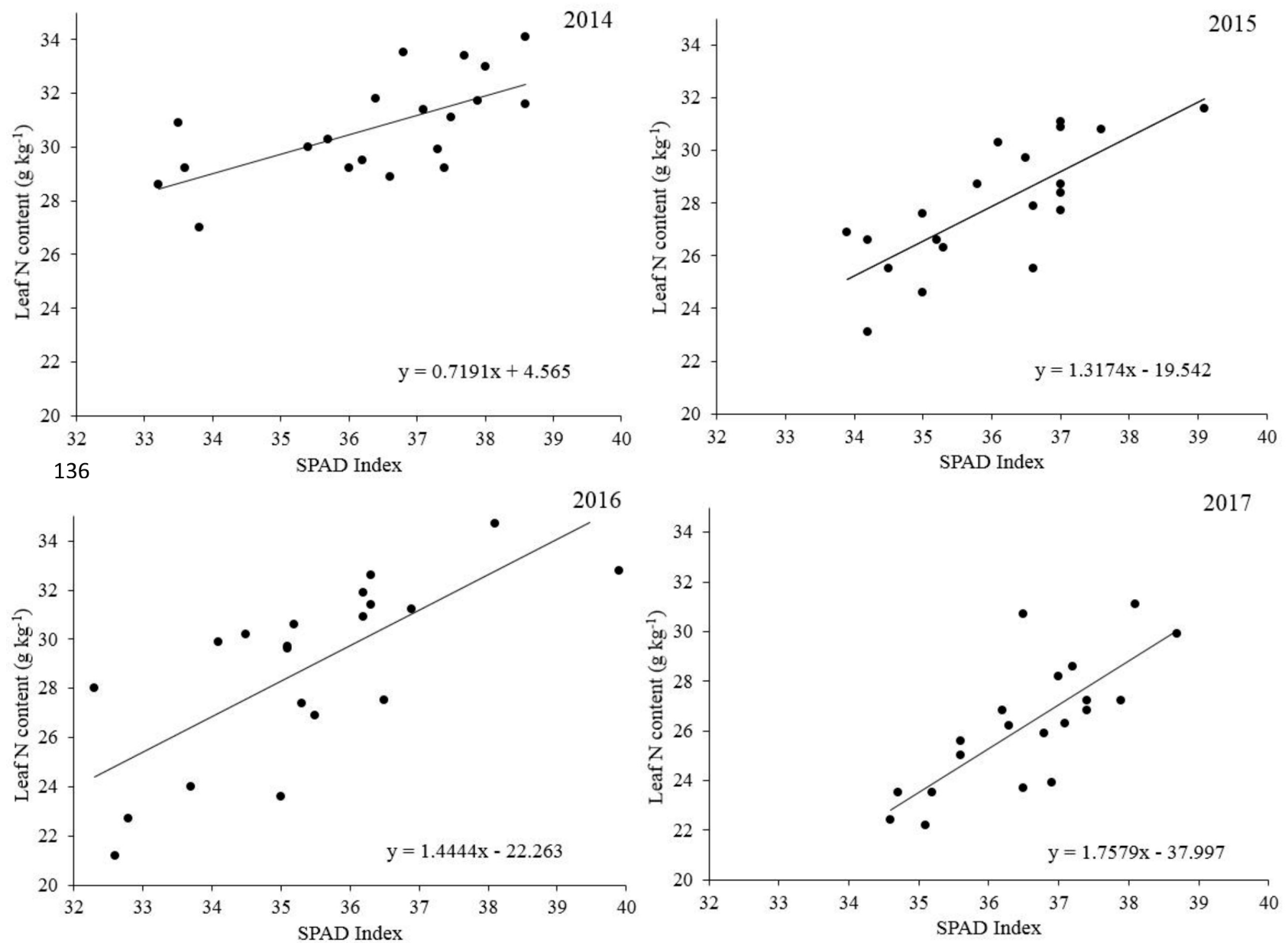

Data were tested for normality distribution by the Shapiro Wilk test and subjected to analysis of variance (ANOVA). The variables that were significant by $\mathrm{F}$ test at $5 \%$ probability were subjected to regression analysis to adjust equations. Statistical analyses were performed with the Sisvar 5.6 software (FERREIRA, 2014). The relationships between variables were obtained using Pearson's correlation coefficient $(p<0.05)$.

\section{Results and Discussion}

The SPAD index showed a direct correlation with leaf N content. For the years 2015, 2016 and 2017, there was a strong significant correlation $(0.756 ; 0.762$ and 0.767 , respectively), however, for 2014, data showed a significant moderate correlation (0.652). Results showed in Figure 1 indicate relationship between the increase in leaf $\mathrm{N}$ content and SPAD index, demonstrating a positive linear relationship.

Figure 1. Relationship between leaf $\mathrm{N}$ content $\left(\mathrm{g} \mathrm{kg}^{-1}\right)$ and SPAD readings in 'Esmeralda' peach in the years 2014, 2015,2016 and 2017 of evaluation $\left(R^{2}=0.4261 ; R^{2}=0.5727 ; R^{2}=0.5278\right.$ and $R^{2}=0.5886$, respectively). 
According to recommendations for the States of Rio Grande do Sul and Santa Catarina (CQFS-RS/SC, 2016), the leaf $\mathrm{N}$ content considered "normal" for peach ranges from 33 to $45 \mathrm{~g} \mathrm{~kg}^{-1}$. These values (y) were achieved with SPAD readings between 39 and 56 in $2014(y=0.7191 x+$ 4.565), between 39 and 49 in $2015(\mathrm{y}=1.3174 \mathrm{x}-19.542)$, between 38 and 47 in $2016(\mathrm{y}=1.444 \mathrm{x}-22.263)$ and between 40 and 47, in $2017(y=1.77579 x-37.5886)$.

According to our data, there are relationship between SPAD index and leaf $\mathrm{N}$ content. This condition was also proven in an experiment with different $\mathrm{N}$ doses applied to the soil surface for apples (NAVA and CIOTTA, 2013). However, the different slopes in straight lines in different years evaluated (Figure 1) indicate that SPAD index does not vary only due leaf $\mathrm{N}$ content, but also due to other factors not controlled in the experiment.
This relationship is attributed to 50 to $75 \%$ of the total leaf $\mathrm{N}$ content is part of enzymes that are associated with chloroplasts (SINGH et al., 2010; REINBOTHE et al., 2010). Therefore, since $\mathrm{N}$ is a component of chlorophyll molecule (LEONARDO et al., 2013; TAIZ et al., 2017), the chlorophyll content in peach leaves is positively correlated with SPAD index. However, the low relationship between SPAD index and leaf $\mathrm{N}$ content in the first year (2014) is probably associated with residual effect of $\mathrm{N}$ fertilization carried out prior to the trial set up.

Regardless of the year evaluated, leaf $\mathrm{N}$ content increased linearly, according to the increasing $\mathrm{N}$ doses applied to the soil (Figure 2), similar to the increasing in SPAD index. The positive correlation among nitrogen fertilization doses and SPAD index evidences the possibility of SPAD readings in providing, with satisfactory precision, leaf N content estimation for 'Esmeralda' peach. Such results are similar to other fruit crops, where correlation between leaf $\mathrm{N}$ content and SPAD index was also found for yellow passion fruit (SANTOS et al., 2011), pecan (HARDIN et al., 2012) and apple (NEILSEN et al., 1995; NAVA and CIOTTA, 2013).
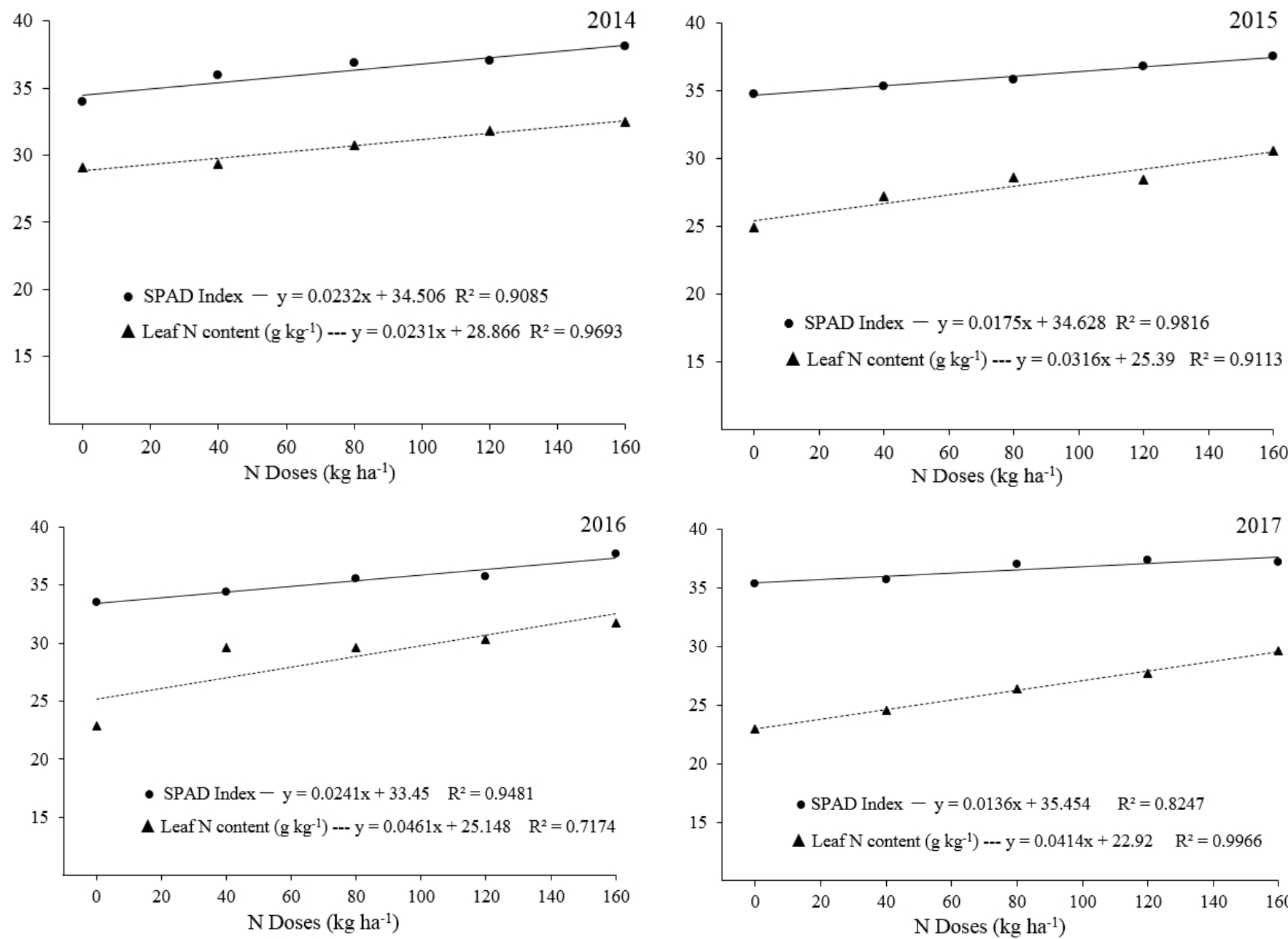

Figure 2. Estimation of leaf $\mathrm{N}$ content $\left(\mathrm{g} \mathrm{kg}^{-1}\right)$ and SPAD index in 'Esmeralda' peach, as a function of $\mathrm{N}$ doses applied to the soil surface during the years 2014, 2015, 2016 and $2017(p<0.05)$. 

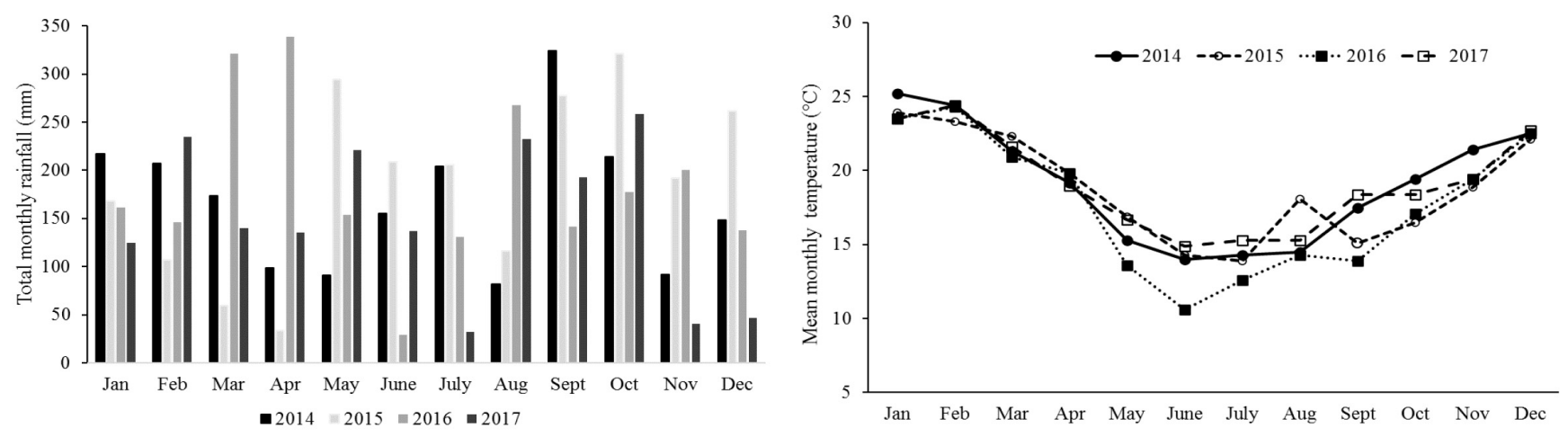

Figures 3. Total monthly rainfall $(\mathrm{mm})$ and average monthly air temperature $\left({ }^{\circ} \mathrm{C}\right)$ in Pelotas, Rio Grande do Sul, Brazil, during the four years trial conduction (AGROMET, 2019).

For evaluated years, the lower average of SPAD index was 39, with means values lower than this indicating leaf $\mathrm{N}$ content is below the critical level, according to $\mathrm{N}$ levels considered normal for peach $\left(33-45 \mathrm{~g} \mathrm{~kg}^{-1}\right)$, requiring soil $\mathrm{N}$ fertilization. The upper average of SPAD index was 49 , which means that values above this showing an excess of leaf $\mathrm{N}$ content, with no need of soil $\mathrm{N}$ fertilization. These results indicate that SPAD index could help to refine soil $\mathrm{N}$ recommendation, since this type of evaluation provides instant results, requiring no additional time for collecting leaf samples, to send to the laboratory and receiving results, avoiding wasted time and money.

Although, in the four analyzed years, the highest $\mathrm{N}$ doses applied to the soil reflected in higher leaf $\mathrm{N}$ content, the differences in the slope of straight lines among years shows that leaf $\mathrm{N}$ concentration depends on other practices besides soil fertilization such as pruning, thinning and climatic conditions, especially rainfall distribution and air temperatures (Figures 3). The rate of soil organic matter mineralization and orchard weed management may also interfere on leaf N content (NAVA and CIOTTA, 2013). Therefore, they need to be better investigated in future research. Such results indicate that similar studies should be carried out for several evaluation years, which allows obtaining more accurate data for SPAD index and possible to be used in $\mathrm{N}$ fertilization recommendations for a wide peach tree cultivars.

\section{Conclusions}

The SPAD index reading responds linearly to the increase in leaf $\mathrm{N}$ content and nitrogen fertilization applied to the soil surface in 'Esmeralda' peach, showing that this index can be used as an indicator of tree $\mathrm{N}$ status and assist in nitrogen fertilization management.

For SPAD evaluations carried out between the $13^{\text {th }}$ and $15^{\text {th }}$ weeks after full blooming of 'Esmeralda' peach, values of SPAD index between 39 and 49 indicate that trees have leaf $\mathrm{N}$ content within the "normal" class.

\section{Acknowledgments}

The authors would like to thank the National Council for Scientific and Technological Development Brazil (CNPq) and the Coordination for the Improvement of Higher Education Personnel - Brazil (Capes), for the grant scholarship; the Embrapa Clima Temperado (SEG Projects 02.13.06.001.00.00 and 02.13.06.024.00.00); to the peach grower Mr. Marcos Fiss and family, for their support in carrying out cultural practices.

\section{References}

AGROMET. Laboratório de agrometeorologia. Brasília: CPACT/EMBRAPA. Disponível em: http://agromet.cpact. embrapa.br/. Acesso em: 25 jan 2019.

ALVARES, C.A.; STAPE, J.L.; SENTELHAS, P.C.; MORAES GONÇALVES, J.L.; GERD, S. Köppen's climate classification map for Brazil. Meteorologische Zeitschrift, Stuttgart, v.22, n.6, p.711-728, 2013.

AMARANTE, C.V.T. do; STEFFENS, C.A.; ZANARDI, O.Z.; ALVES, E.O. Quantificação de clorofilas em folhas de macieiras 'Royal Gala' e 'Fuji' com métodos ópticos não-destrutivos. Revista Brasileira de Fruticultura, Jaboticabal, v.30, n.3, p.590-595, 2008.

BRUNETTO, G.; TRENTIN, G.; CERETTA, C.A.; GIROTTO, E.; LORENSINI, F.; MIOTTO, A.; MOSER, G.R.Z.; MELO, G. W. de. Use of the SPAD-502 in estimating nitrogen content in leaves and yield in grapevines in soils with different texture. American Journal of Plant Sciences, Ixtacuaco, v.3, n.11, p.1546$1561,2012$.

CABANGON, R.J.; CASTILlo, E.G.; TUONG, T.P. Chlorophyll meter-based nitrogen management of rice grown under alternate wetting and drying irrigation. Field Crops Research, Amsterdam, v.121, n.1, p.136-146, 2011. 
CEROVIC, Z.G.; GHOZLEN, N.B.; MILHADE, C.; OBERT, M.; DEBUisson, S.; MOIGNE, M. Nondestructive diagnostic test for nitrogen nutrition of grapevine (Vitis vinifera L.) based on dualex leaf-clip measurements in the field. Journal of Agricultural and Food Chemistry, Washington, v.63, n.14, p.3669-3680, 2015.

CQFS-RS/SC - Comissão de Química e Fertilidade do Solo. Manual de adubação e de alagem para os estados do Rio Grande do Sul e Santa Catarina. 10.ed. Porto Alegre: Núcleo Regional Sul - Sociedade Brasileira de Ciência do Solo, 2004. 400 p.

CQFS-RS/SC - Comissão de Química e Fertilidade do Solo. Manual de calagem e adubação para os Estados do Rio Grande do Sul e de Santa Catarina. 11.ed. Frederico Westphalen: Núcleo regional Sul - Sociedade Brasileira de Ciência do Solo, 2016. 376 p.

EMBRAPA- Empresa Brasileira de Pesquisa Agropecuária. Sistema brasileiro de classificação de solos. 3.ed. Brasília: Centro Nacional de Pesquisa de Solos, 2013. $353 \mathrm{p}$.

FERREIRA, D.F. Sisvar: a guide for its bootstrap procedures in multiple comparisons. Ciência e Agrotecnologia, Lavras, v.38, n.2, p.109-112, 2014.

FERREIRA, D.F. Estatística básica. 2.ed. Lavras: UFLA, 2009. 664p.

GARRIZ, P. I.; COLAVITA, G. M.; ALVAREZ, L. A. Leaf characteristics and fruit growth as influenced by shade in 'Braeburn' apple trees. Revista Ceres, Viçosa, v.48, n.278, p.437-444, 2001.

HARDIN, J.A.; SMITH, M.W.; WECKLER, P.R.; CHEARY, B.S. In situ measurement of pecan leaf nitrogen concentration using a chlorophyll meter and vis-near infrared multispectral camera. HortScience, Alexandria, v.47, n.7, p.955-960, 2012.

KAZMIER, L.J. Estatística aplicada à administração e economia. 4.ed. Porto Alegre: Bookman, 2007. 392p.

LEONARDO, F.A.P.; PEREIRA, W.E.; SILVA, S.M.; COSTA, J.P. da. Teor de clorofila e índice SPAD no abacaxizeiro cv. Vitória em função da adubação nitrogenada. Revista Brasileira de Fruticultura, Jaboticabal, v.35, n.2, p.377-383, 2013.

MARSCHNER P. Marschner's mineral nutrition of higher plants. 3.ed. London: Academic Press, 2012. 651p.

MINOLTA, K. Chlorophyll meter SPAD-502. Instruction manual. Osaka: Radiometric Instruments Operations., 1989. 22 p.

NAVA, G.; CIOTTA, M.N. Viabilidade do uso do SPAD no diagnóstico do Estado de Nitrogênio na macieira Fuji. Revista de Ciências Agroveterinárias, Lages, v.12, n.1, p.13-20, 2013.
NEILSEN, D.; HOGUE, E.J.; NEILSEN, G.H; PARCHOMCHUK, P. Using SPAD-502 values to assess the nitrogen status of apple trees. HortScience, Alexandria, v.30, n.3, p.508-512, 1995.

PORRO, D.; DORIGATTI, C.; STEFANINI, M.; CESCHINI, A. Use of SPAD meter in diagnosis of nutritional status in apple and grapevine. Acta Horticulturae, The Hague, v.564, p.243-252, 2001.

PRADO, R.M.; VALE, D.W. Nitrogênio, fósforo e potássio na leitura SPAD em porta-enxerto de limoeiro cravo. Pesquisa Agropecuária Tropical, Goiânia, v.38, n.4, p.227-232, 2008.

RASEIRA, M.C.B.; PEREIRA, J.F.M.; CARVALHO, F.L.C. (org.). Pessegueiro. Brasília (DF): Embrapa, 2014. $776 \mathrm{p}$.

REINBOTHE, C.; BAKKOURI, M.E.; BUHR, F.; MURAKI, N.; NOMATA, J.; KURISU, G.; FUJITA, Y.; REINBOTHE, S. Chlorophyll biosynthesis: spotlight on protochlorophyllide reduction. Trends in Plant Science, Amsterdam v.15, n.11, p.614-624, 2010.

ROBERTS, I.N.; CAPUTO, C.; CRIADO, M.V.; FUNK, C. Senescence associated proteases in plants. Physiologia Plantarum, Escandinava, v.145, n.1, p.130-139, 2012.

SANTOS, P.C. dos; LOPES, L.C.; FREITAS, S.J.; SOUSA, L.B. de; CARVALHO, A.J.C. de. Crescimento inicial e teor nutricional do maracujazeiro amarelo submetido à adubação com diferentes fontes nitrogenadas. Revista Brasileira de Fruticultura, Jaboticabal, v.33, p.722-728, 2011. Volume especial.

SINGH, V.; SINGH, B.; SINGH, Y.; THIND, H.S.; GUPTA, R.K. Need based nitrogen management using the chlorophyll meter and leaf colour chart in rice and wheat in South Asia: a review. Nutrient Cycling Agroecosystems, Ithaca, v.88, p.361-380, 2010.

SOIL SURVEY STAFF. Soil taxonomy. 2.ed. Washington: United States Department of Agriculture, 1999.

SOUZA, T.R.; SALOMÃO, L.C.; ANDRADE, T.F. de; VILLAS BÔAS, R.L.; GUAGGIO, J.A. Medida indireta da clorofila e sua relação com o manejo da adubação nitrogenada em plantas cítricas fertirrigadas. Revista Brasileira de Fruticultura, Jaboticabal, v.33, n.3, p.9931003, 2011.

TAIZ, L.; ZEIGER, E. Fisiologia e desenvolvimento vegetal. 6.ed. Porto Alegre, Artmed Editora, 2017. 858p.

TREDER, W.; KLAMKOWSKI, K.; KOWALCZYK, W.; SAS, D.; WÓJCIK, K. Possibilities of using image analysis to estimate the nitrogen nutrition status of apple trees. Zemdirbyste-Agriculture, Berlim, v.103, n.3, p.319-326, 2016. 